\title{
In-situ carbonization of natural zeolite-alumina composite materials incorporated sawdust
}

JAMAL-ELDIN F. M. IBRAHIM - Institute of Ceramics and Polymer Engineering, University of Miskolc, Hungary - jamalfadoul@gmail.com Sudan, he graduated from University of Marmara, Istanbul, Turkey, Institute of Pure and Applied Sciences, Department of Metallurgical and Materials Engineering, for the time being, he is a PhD student in the University of Miskolc, Institute of Polymer and Ceramics Engineering, under supervision of Prof. L. A. Gömze.

AfanAsy S. APKARIAN - Institute of Strength Physics and Materials Science SB RAS, National Research Tomsk State University

Mohammed TIHTIH - Institute of Ceramics and Polymer Engineering, University of Miskolc, Hungary - medtihtih@gmail.com

SERGEI N. KULKOV - Institute of Strength Physics and Materials Science SB RAS, National Research Tomsk State University • kulkov@ms.tsc.ru

LÁszLó A. GÖMZE - Institute of Ceramics and Polymer Engineering, University of Miskolc, Hungary, IGREX Engineering Service Ltd, · femgomze@uni-miskolc.hu Érkezett: 2021. 06. 03. - Received: 03. 06. 2021. " https://doi.org/10.14382/epitoanyag-jsbcm.2021.20

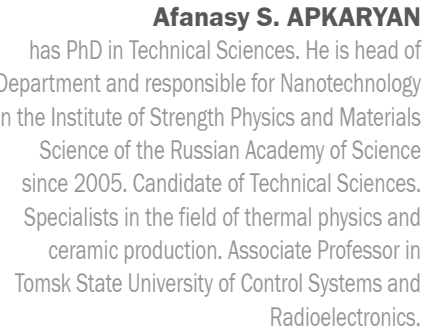

Mohammed TIHTIH

\section{Abstract}

This research study investigates the potential use of traditional raw materials to synthesize new ceramic composite materials that can be used in different industrial applications. The composite materials were developed through mechanical activation, carbonization, and reactive sintering techniques. Natural zeolite from Tokaj region, alumina from Motim, and sawdust were used as starting raw materials. Stoichiometric amounts of the raw materials were mixed and milled in planetary ball milling followed by uniaxially pressing to produce cylindrical ceramic discs. The produced green ceramics were then sintered in an electric laboratory kiln under an oxygen-free environment at $1200{ }^{\circ} \mathrm{C}$. In-situ carbonization of the sawdust was confirmed via X-ray diffraction. The thermal properties were also investigated by derivatography. The produced ceramic specimens were tested on microstructural characteristics, porosity, density, and water absorption

Keywords: alumina, derivatography, sawdust, SEM, XRD, zeolite

Kulcsszavak: alumínium-oxid, derivatográf, fúrészpor, SEM, XRD, zeolit

\section{Introduction}

Nowadays, ceramics and ceramic composites play an important role in the industries due to the high need for porous materials with superior physical, chemical, and mechanical properties [1-8]. Many research works have been carried out to synthesize ceramics and ceramic matrix composites for different applications to satisfy this increased demand [9-12]. Several research studies focus on using relatively cheap raw materials to produce cost-effective composite materials [13-15]. Mullite strengthened carbon and silicon carbide composites are drawn a huge interest recently [16-18]. Due to their superior properties, such as relatively low density, good thermal stability, and oxidation resistance. These good characteristics make mullitebased composites a material of choice for different applications, especially optical and electronic device applications and hightemperature applications, for instance, refractory materials and coatings for a turbine blade [19-20]. The main reason beyond the synthesis of the composite materials is to overcome the brittleness of the monolithic ceramics, which restricts their applications.

Mullite $\left(3 \mathrm{Al}_{2} \mathrm{O}_{3} \cdot 2 \mathrm{SiO}_{2}\right)$ is an important material for both traditional and advanced ceramics. Due to its outstanding characteristics such as low thermal conductivity, low thermal expansion coefficient, and superior creep resistance, high resistance to corrosive environments, and high-temperature strength [21-22]. The formation of the mullite phase is normally taking place upon the reaction of silica $\left(\mathrm{SiO}_{2}\right)$ with alumina $\left(\mathrm{Al}_{2} \mathrm{O}_{3}\right)$

\section{Is a lecturer in the Sidi Mohamed Ben abdellah University, Morocco, he graduated from Faculty of sciences Dhar El Mahraz, Fez, Morocco, Department of Physics, for the time being, he is a $\mathrm{PhD}$ student in the University of Miskolc, Institute of Ceramics and Polymer Engineering, under supervision of Prof. L. A. Gömze.} is professor of the Tomsk State University and head of Department of Ceramics in the Institute of Strength Physics and Materials Science of the Russian Academy of Science since 1989. His research works are represented in 5 books, more than 150 articles, 18 patents and many International Symposiums and Conferences. At present he is head of department "Theory of Strength and Mechanic of Solids", member of "The American Ceramic Society” of "The APMI International" and the DYM AT Society (France).

László A. GÖMZE is establisher and professor of the Department of Ceramics and Silicate Engineering in the University of Miskolc, Hungary. He is author or coauthor of 2 patents, 6 books and more than 300 scientific papers. Recently, he is the chair of the International Organization Board of ic-cmtp6 the $6^{\text {th }}$ International Conference on Competitive Materials and Technological Processes and ecsiliconf2 the $2^{\text {nd }}$ European Conference on Silicon and Silica Based Materials.

at a temperature above $1000{ }^{\circ} \mathrm{C}[23]$. The morphology and purity of the mullite phase depend on the raw materials composition, preparation method, and sintering temperature. Fig. 1 illustrates the phase diagram of the $\mathrm{SiO}_{2}-\mathrm{Al}_{2} \mathrm{O}_{3}$ system. In this system, mullite is the only stable intermediate phase at atmospheric pressure. Mullite is normally found in man-made ceramics; it can rarely be found in nature [20]. Mullite structure can incorporate variable cations such as $\mathrm{Ga}^{3+}, \mathrm{B}^{3+}, \mathrm{Na}^{+}, \mathrm{Mg}^{2+}, \mathrm{Eu}^{2+}$ etc., in different concentrations [24]. A dense mullite ceramic with high purity is difficult to synthesize through the traditional sintering techniques; normally, a porous ceramic with a glassy phase is obtained [25].

Carbonization is a thermochemical process in which high carbon content is produced through thermal degradation of biomass normally by pyrolysis in a reduction environment [26]. The carbonization is highly affected by temperature, moisture content, and biomass composition. Wood usually consist of cellulose (48\%), hemicellulose (19\%), lignin (24\%) extractive (7.5\%), Ash (1.6\%) and moisture (33\%). The amount
Sergei N. KULKOV 
of these constituents varies from one plant species to another [27]. The cellulose consists of straight-chain macromolecules; it has a crystalline nature and is normally incorporated in a matrix of hemicellulose and lignin [28]. Cellulose is the major constituent of biomass. In contrast, hemicellulose has an amorphous structure with a low degree of polymerization. Lignin is a phenolic compound consist of a randomly connected amorphous structure that has high molecular weight. Therefore, the carbonization of these constituents takes place through a series of complex reactions [29]. This process can be observed on thermogravimetry of the biomass. The complex carbonization mechanisms could be divided into five stages. Firstly, upon heating, drying of the biomass takes place with the evaporation of some volatile organic compounds. Secondly, hemicellulose's thermal decomposition will take place to yield organic acids, methanol, and some gases. The next step involves the emission of carbon monoxide, carbon dioxide, some hydrocarbons (methane, ethane, ethylene), and some acids. After that, cellulose decomposes to give water, carbon dioxide, and carbon (charcoal). Moreover, lignin also decomposes into phenolic compounds and methanol. Finally, the carbonization is complete with the full conversion of lignin into carbon and emission of the hydrogen gas [27]. The aim of this research work was to produce composite materials based on mullite and carbon through in-situ carbonization and reactive sintering of different mixtures of $\mathrm{Al}_{2} \mathrm{O}_{3}$, natural zeolite, and sawdust, to investigate the technical feasibility of the carbonization process and to evaluate the technical features and microstructural characteristics of the produced samples.

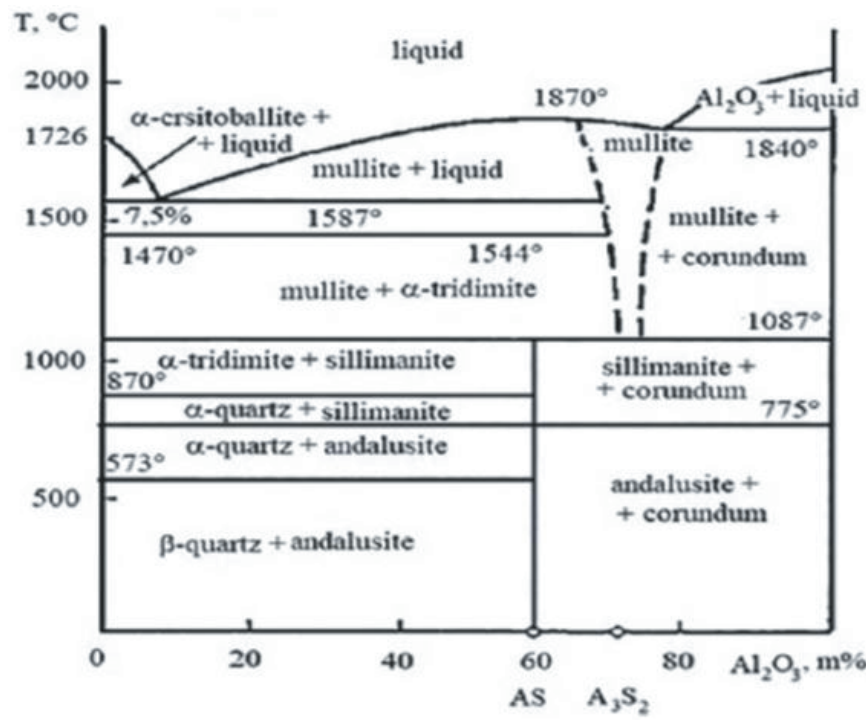

Fig. $1 \mathrm{SiO}-\mathrm{Al}_{2} \mathrm{O}_{3}$ phase diagram [30]

1. ábra $\mathrm{SiO}_{2}-\mathrm{Al}_{2} \mathrm{O}_{3}$ fázisdiagram [30]

\section{Materials and experiments}

\subsection{Materials}

Natural zeolite of high availability mined from Tokaj region in Hungary was initially chosen for this study as silica $\left(\mathrm{SiO}_{2}\right)$ source because of their high silica content (83\%), alumina from MOTIM company (Hungary) with a purity of $98 \%$ was used as primary raw materials. Whilst sawdust which was collected as waste material was used as a carbon source. $60 \mathrm{wt} \%$ of alumina and $40 \mathrm{wt} \%$ natural zeolite were taken and mixed with various sawdust percentages $(5 \%, 10 \%, 20 \%$, and $30 \%)$.

\subsection{Methods}

Ceramics composites based on alumina, natural zeolite, and sawdust were produced by tuning the sawdust content, as shown in Fig. 2. The stoichiometric amount of the raw materials were taken according to the Table. 1, mixed and dry-milled for 20 minutes in planetary ball-milling at $200 \mathrm{rpm}$. The produced powders mix were then uniaxially dry-compacted at $40 \mathrm{MPa}$ to form green ceramic discs with a size of $25 \mathrm{~mm}$ in diameter and $10 \mathrm{~mm}$ in thickness. The mechanical pressing process was intended to achieve closer contact between the reactants, which can enhance the physicochemical reaction rate. The prepared ceramic specimens were pressureless sintered in an electric laboratory kiln at $1200{ }^{\circ} \mathrm{C}$ in a reduction environment in a sealed container. The heating rate and residence time at the maximum temperatures were $30^{\circ} \mathrm{C} / \mathrm{h}$ and $3 \mathrm{~h}$, respectively.

\begin{tabular}{ccc} 
Alumina (wt\%) & Natural zeolite (wt\%) & Sawdust (wt\%) \\
\hline 60 & 40 & 0 \\
\hline 60 & 40 & 5 \\
\hline 60 & 40 & 10 \\
\hline 60 & 40 & 20 \\
\hline 60 & 40 & 30
\end{tabular}

Table 1. The percentage of the raw materials used to prepare the mixtures 1. táblázat A keverékek elkészitéséhez felhasznált nyersanyagok százalékos aránya

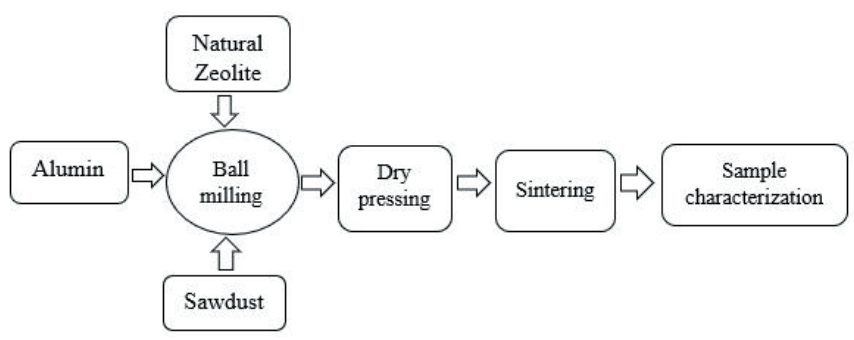

Fig. 2 Flowchart for the production of the ceramic samples

2. ábra Folyamatábra a kerámiaminták elóálításához

\subsection{Characterization techniques}

Phase identification of the raw materials and the sintered specimens were analyzed using an X-ray diffractometer (Rigaku Miniflex II) with CuKa radiation $(\lambda=1.54184 \AA)$, The scanning speed was $1 \%$ min in $2 \theta$ intervals of $0-90^{\circ}$ and a step size of $0.01015^{\circ}$. The oxide composition of the natural zeolite we examined via X-ray fluorescence (XRF). The thermal properties of the raw materials powders were analyzed by thermogravimetry (TG) and differential thermal (DTA) analyses using a thermal analyzer (setsys evolution 1750 SETARAM). All the thermal tests were done in air at a heating rate of $5{ }^{\circ} \mathrm{C} / \mathrm{min}$. The microstructural characteristics of the fracture surface of the produced composite materials were done using scanning electron microscopy (SEM, S-4800, Hitachi, Japan) at an accelerating voltage of $10 \mathrm{kV}$. Different technical characteristics, including apparent porosity, bulk density, water absorption, and volume shrinkage of the fired ceramic specimens, were obtained using Archimedes technique. 


\section{Results and discussions}

The investigation of the prepared ceramic specimens confirms that tuning the amount of the sawdust leads to different colours and shrinkages of the samples (Fig. 3). This could be attributed to the physicochemical reactions, which highly alter the microstructure and the properties of the samples.

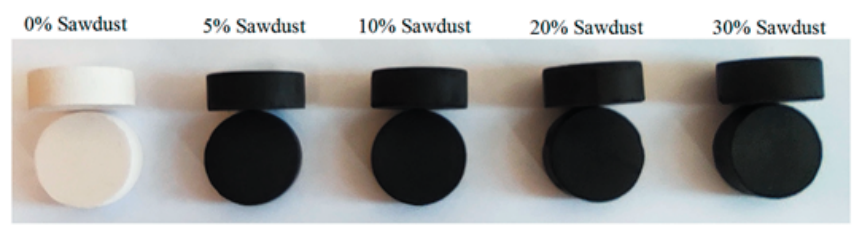

Fig. 3 Produce ceramic samples with different percentage of sawdust

3. ábra Különböző arányú fürészporral készült kerámiaminták

\subsection{XRD investigations}
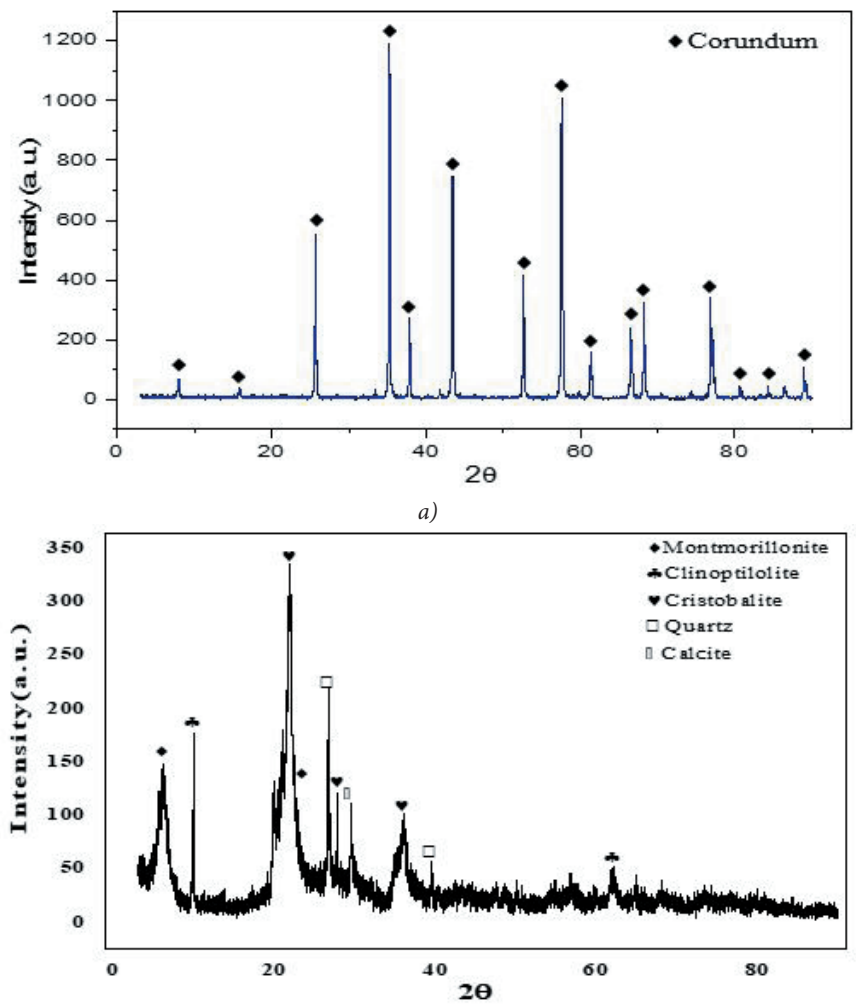

b)

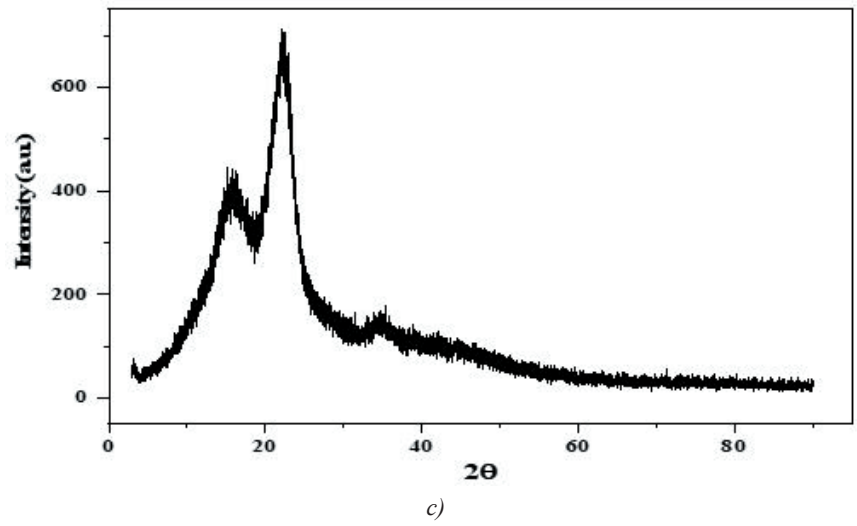

Fig. 4 XRD diffraction pattern of a) alumina, b) natural zeolite, and c) sawdust 4. ábra a) alumínium-oxid, b) természetes zeolit és c) fürészpor XRD diffrakciós mintázata
Fig. 4 a shows the XRD analysis of the alumina, which reveals the presence of single-phase corundum. The XRD patterns of natural zeolite (Fig. 4.b) show different mineral phases, including montmorillonite, clinoptilolite, cristobalite, quartz, and calcite. The XRD diffractogram of sawdust (Fig. 4.c) shows two peaks at $2 \theta 15.5^{\circ}$ and $22.5^{\circ}$, which indicate the cellulose I, moreover at $2 \theta=34.6^{\circ}$, a small peak is observed which assigned to cellulose I. lignin and hemicellulose, which have an amorphous structure, are expected to exist in sawdust beside the crystalline cellulose.

Table 2 shows the amount of oxide composition and loss on ignition (LOI) of the natural zeolite obtained from XRF analysis. The major phases were found to be silica with almost $83 \%$ and alumina with almost $6 \%$, while the minor phases were $\mathrm{MgO}, \mathrm{Na}_{2} \mathrm{O}$, and $\mathrm{CaO}$.

\begin{tabular}{|c|c|c|c|c|c|c|c|c|}
\hline \multirow{2}{*}{$\begin{array}{c}\text { Raw } \\
\text { material }\end{array}$} & \multicolumn{8}{|c|}{ Oxides content, $\%$} \\
\hline & CaO & $\mathrm{SiO}_{2}$ & $\mathrm{Al}_{2} \mathrm{O}_{3}$ & MgO & $\mathrm{Na}_{2} \mathrm{O}$ & $\mathrm{CO}_{2}$ & $\mathrm{H}_{2} \mathrm{O}$ & $\begin{array}{l}\text { Loss on } \\
\text { ignition }\end{array}$ \\
\hline $\begin{array}{l}\text { Natural } \\
\text { zeolite }\end{array}$ & 1.12 & 82.92 & 5.95 & 3.21 & 1.31 & 0.88 & 2.87 & 5.50 \\
\hline $\begin{array}{r}\text { Table } 2 \\
\text { 2. táblázat }\end{array}$ & $\begin{array}{l}\text { emic } \\
\text { erm }\end{array}$ & tes & $\begin{array}{l}n \text { of } t \\
\text { cémia }\end{array}$ & zeté & olite & & & \\
\hline
\end{tabular}

\subsection{SEM investigation of the raw materials}

The microstructural properties and morphological characteristics of the raw materials are shown in Fig. 5; alumina has a smaller grain size than natural zeolite, which has a relatively larger particle size with irregular shape, while the sawdust has an irregular shape with a porous structure.

\subsection{Thermal properties of raw materials}

TG/DTA curves of the natural zeolite are shown in Fig. 6.a. An overall weight loss of about $10.4 \%$ was recorded at 1200 ${ }^{\circ} \mathrm{C}$. Firstly, 5.5\% weight loss was obtained between 40 and $201.3^{\circ} \mathrm{C}$. This weight loss is attributed to the removal of free water. Secondly, $2.06 \%$ weight loss was observed between 201.3 to $524.6{ }^{\circ} \mathrm{C}$, which assigned to the evaporation of combined water and burned out of organic content. Finally, a weight loss of $2.84 \%$ is achieved between 524.6 and $739^{\circ} \mathrm{C}$, which could be attributed to the firing of the organic content. In DTA curve, several peaks are observed, at $111^{\circ} \mathrm{C}$, an endothermic peak is remarked, this peaks could be designated to the removal of free water, two outstretched peaks are noticed between $201.3^{\circ} \mathrm{C}$ and $704.6^{\circ} \mathrm{C}$, which possibly indicates the removal of crystalline water and burning of the organic matter.

Fig. 6 b shows the TG/DTA graphs of the sawdust. The TG graph shows a total weight loss of about $86.4 \%$ split into three steps of thermal disintegration. In the first step, a weight loss of $4.6 \%$ is recorded at a temperature between $40-238{ }^{\circ} \mathrm{C}$; this weight loss might be due to the removal of free water (drying). In the second step, a weight loss of $43.7 \%$ was achieved in the temperature range of 238 to $333.8{ }^{\circ} \mathrm{C}$, which could be assigned to the evaporation of the volatile organic content. Finally, 38.07\% weight loss is observed in a temperature range of 333.8-647.4 ${ }^{\circ} \mathrm{C}$, which ascribed to continuous burning of the organic materials achieved from the decomposition of hemicellulose, cellulose, and lignin. In the DTA graph, 
broad exothermic peaks are observed in the temperature between 233-659.5 ${ }^{\circ} \mathrm{C}$, which could be assigned to the thermal disintegration of hemicellulose, cellulose, and lignin respectively. The decomposition of hemicellulose normally takes place at a lower temperature since it has a smaller chain with a linear structure, while the decomposition of cellulose and lignin takes place at a relatively high temperature due to their complex structure.
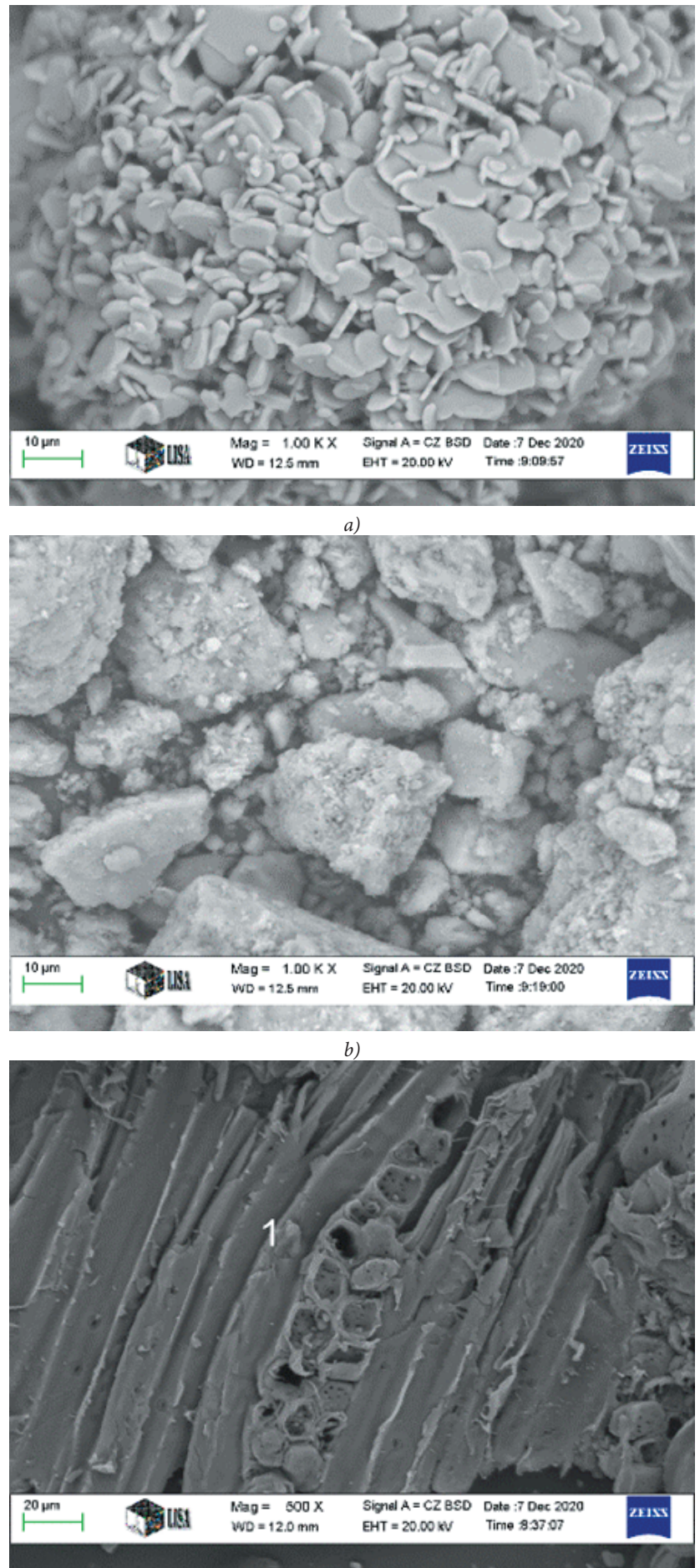

c)

Fig. 5 Scanning electron microscope images of a) alumina, b) natural zeolite c) sawdust

5. ábra a) alumínium-oxid, b) természetes zeolit, c) fürészpor pásztázó elektronmikroszkópos felvétele
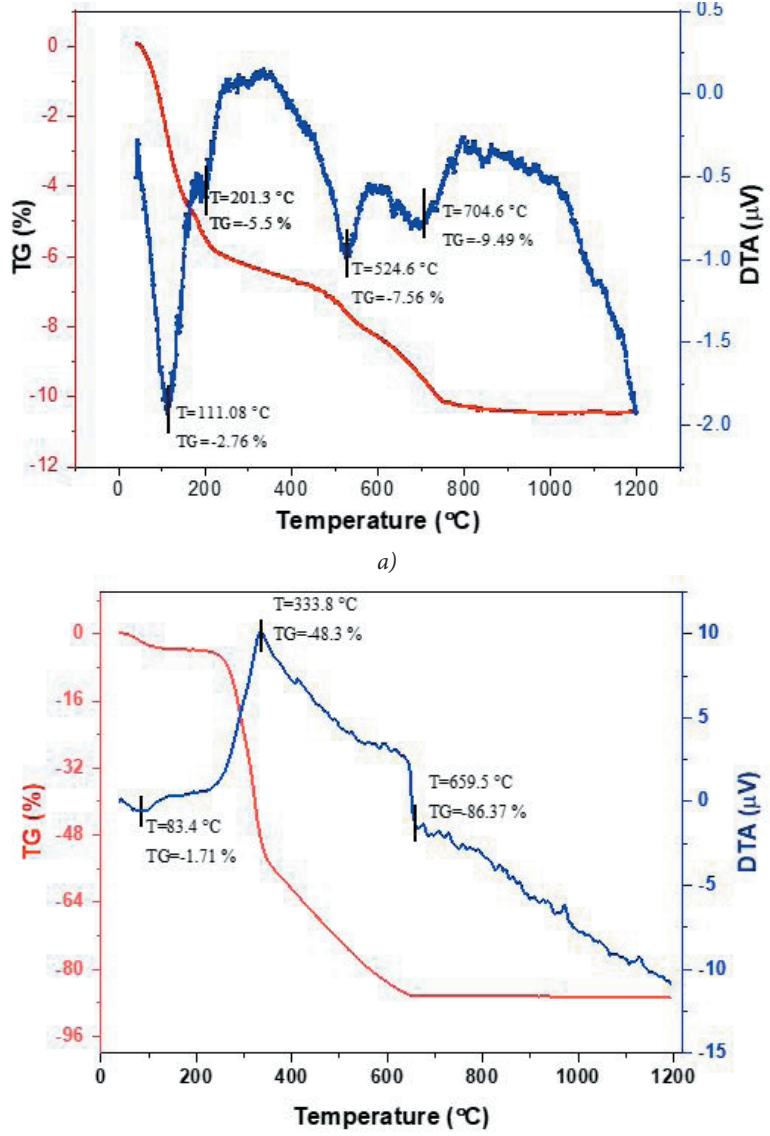

b)

Fig. 6 DTA and TG curves of a) natural zeolite, b) sawdust 6. ábra a) természetes zeolit, b) fürészpor DTA és TG görbéi

\subsection{XRD investigations of the produced ceramic samples}

Fig. 7 show the XRD analysis of the sintered ceramic samples, which reveal the decomposition of clinoptilolite, montmorillonite, and calcite and the occurrence of some phsicochemical reaction that yields a mullite phase. It is worth mentioning that the XRD investigation could not detect the carbon indicating that amorphous carbon is formed.

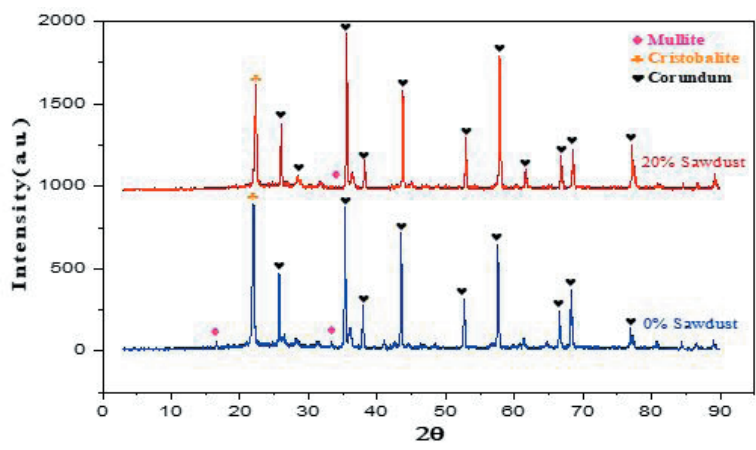

Fig. 7 XRD diffraction pattern of the produced ceramic samples 7. ábra Az elóállított kerámiaminták XRD diffrakciós mintázata

\subsection{Scanning electron microscopy (SEM) of the produced samples}

The morphological features and the microstructural characteristics of the fractured surface of the different ceramic 
samples sintered at a temperature of $1200{ }^{\circ} \mathrm{C}$ are shown in the scanning electron micrographs (Fig. 8). It can be seen that increasing the sawdust content increases the porosity. This occurs due to the effect of carbonization, which converts the biomass into carbon. This process is associated with the evaporation of some organic content leading to pores formation in the samples.
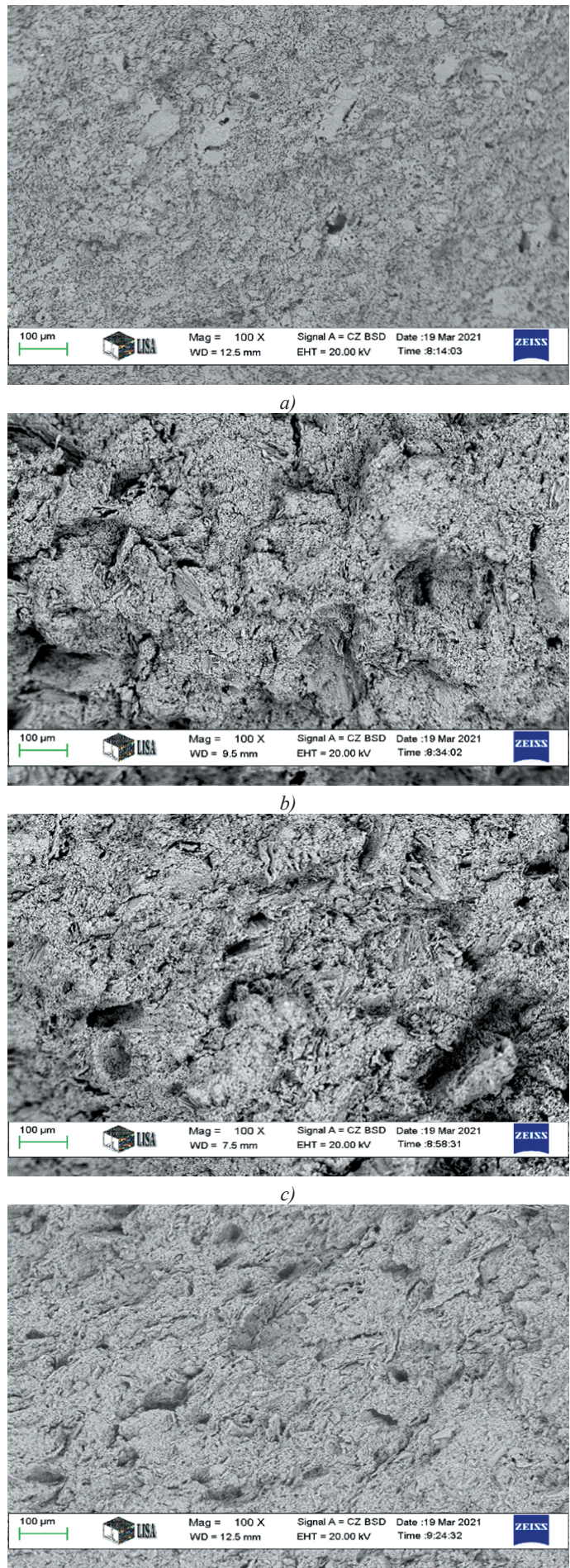

Fig. 8 SEM images of the fracture surface of the sintered samples at $\times 100$ contain a) $0 \%$ sawdust b) $10 \%$ sawdust c) $20 \%$ sawdust, and d) $30 \%$ sawdust

8. ábra a) 0\% fürészport b) $10 \%$ fürészport c) 20\% fürészport és d) 30\% fürészport tartalmazó szinterelt minták töretfelületének 100x-szoros nagyitású SEM felvételei
Fig. 9 exhibit a larger magnification of the fracture surfaces of the samples. A noticeable change can be observed due to the difference in the material compositions. A sheet-like structure with a smooth surface can be seen, which indicate the formation of carbon.
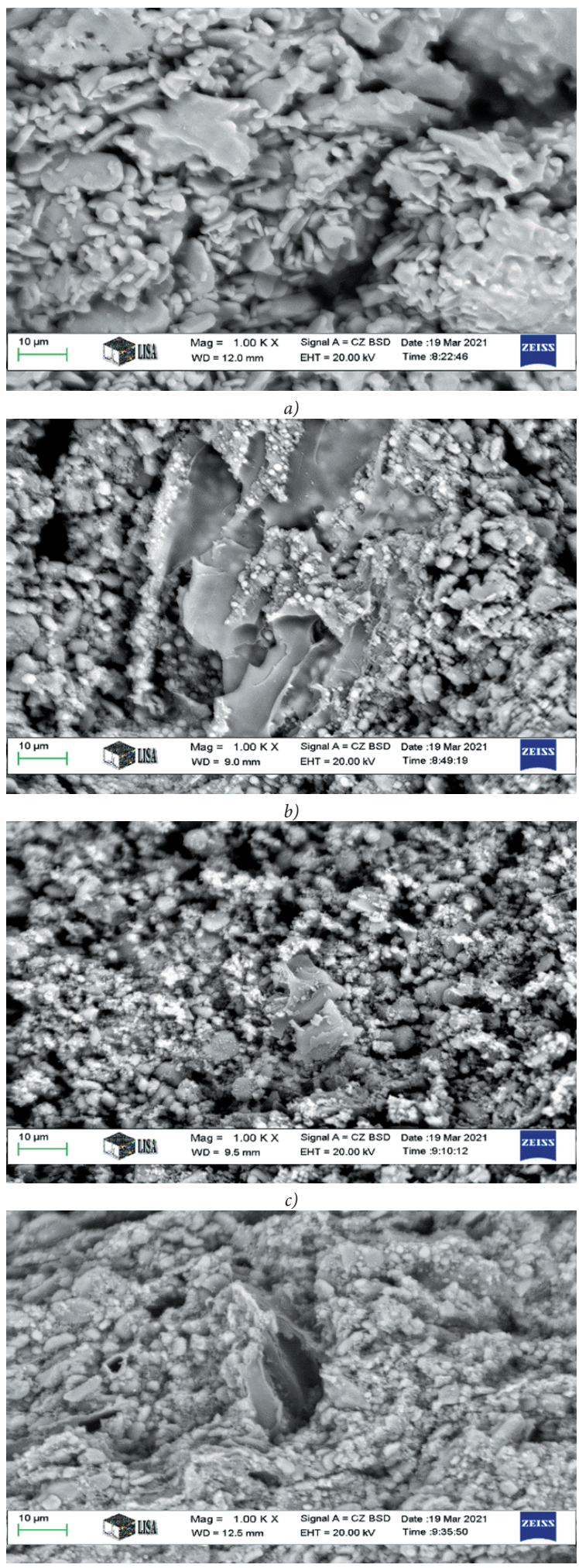

Fig. 9 SEM images of the fracture surface of the sintered samples at $\times 1000$ contain a) $0 \%$ sawdust b) $10 \%$ sawdust c) $20 \%$ sawdust, and d) $30 \%$ sawdust

9. ábra a) 0\% fürészport b) $10 \%$ fürészport c) $20 \%$ fürészport és d) $30 \%$ fürészport tartalmazó szinterelt minták töretfelületének 1000x-szeres nagyítású SEM felvételei 


\subsection{EDS investigation of the produced samples}

EDS analysis of the samples are shown in Fig. 10. It confirms the formation of the carbon in the samples, which is highly influenced by the amount of sawdust used as raw material. Using $10 \%, 20 \%$ and $30 \%$ sawdust lead to the formation of $8 \%$, $10.3 \%$ and $14.54 \%$ of carbon, respectively, in the samples.

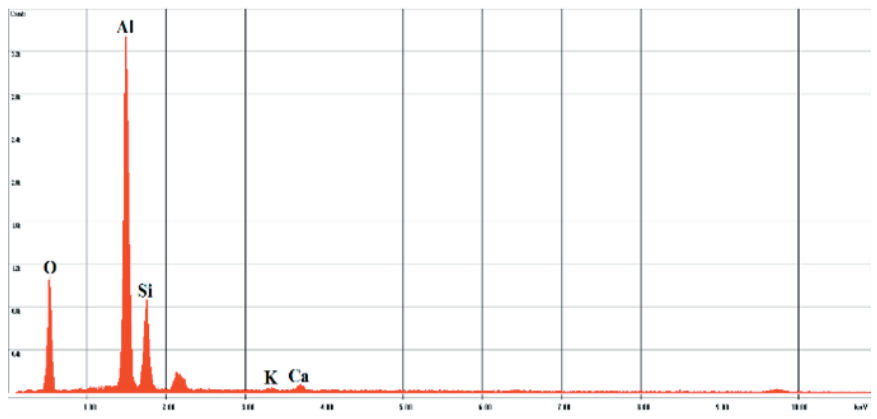

a)

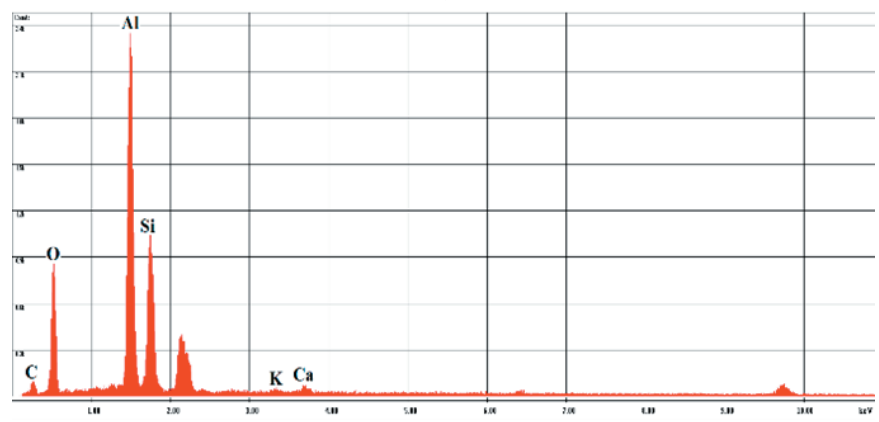

b)

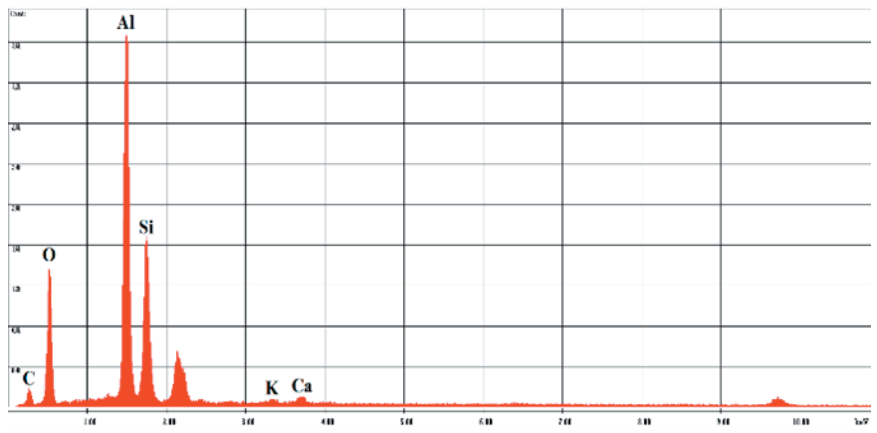

c)

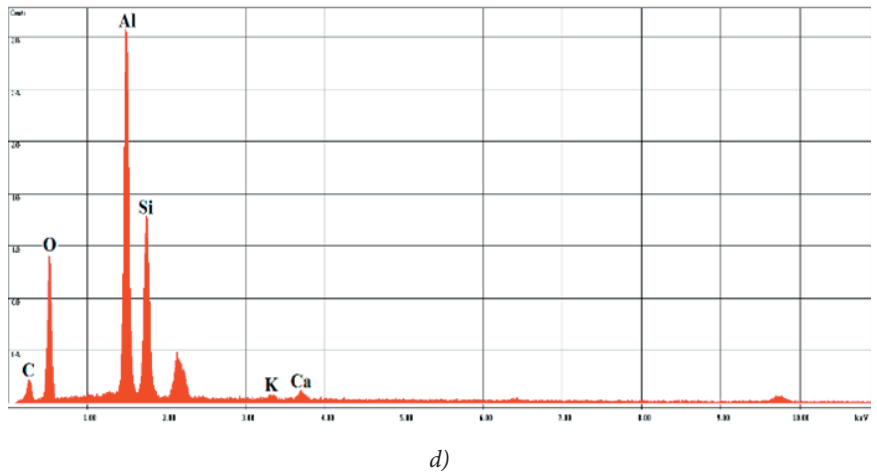

Fig. 10 EDS analysis of the sintered samples contain a) 0\% sawdust b) $10 \%$ sawdust c) $20 \%$ sawdust and d) $30 \%$ sawdust

10. ábra a) 0\% fürészport b) $10 \%$ fürészport c) $20 \%$ fürészport és d) $30 \%$ fürészport tartalmazó szinterelt minták EDS-elemzése
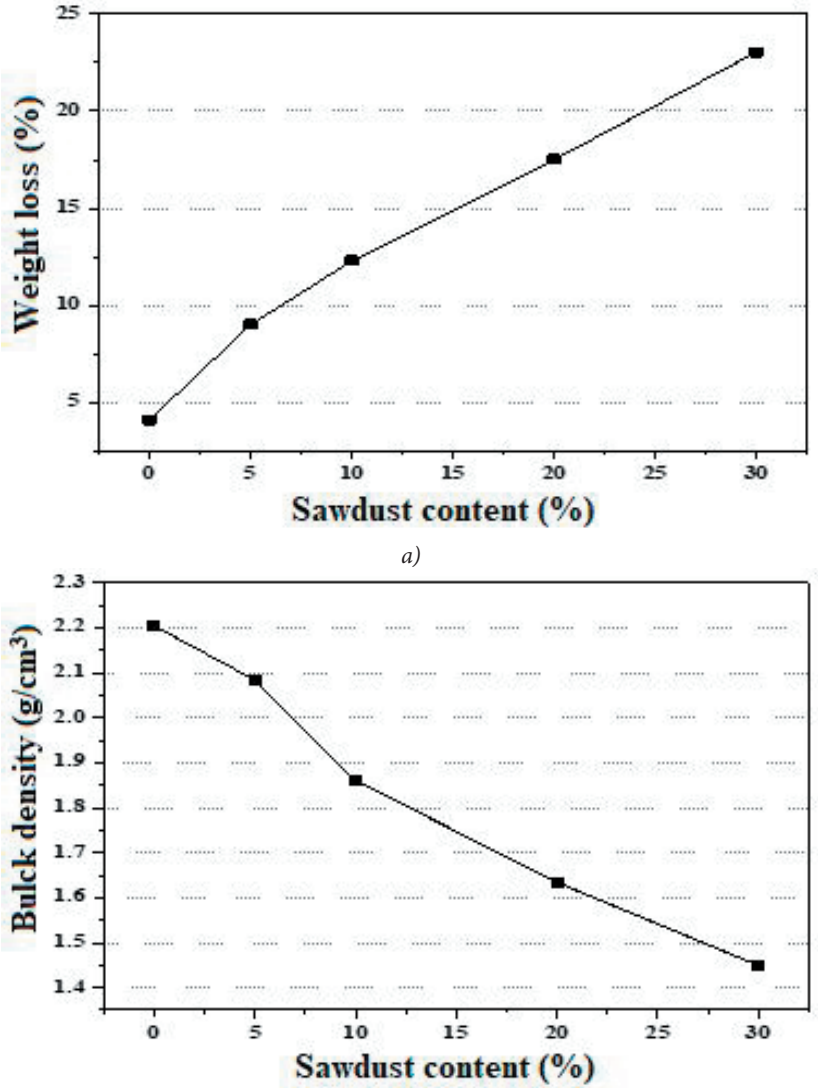

b)
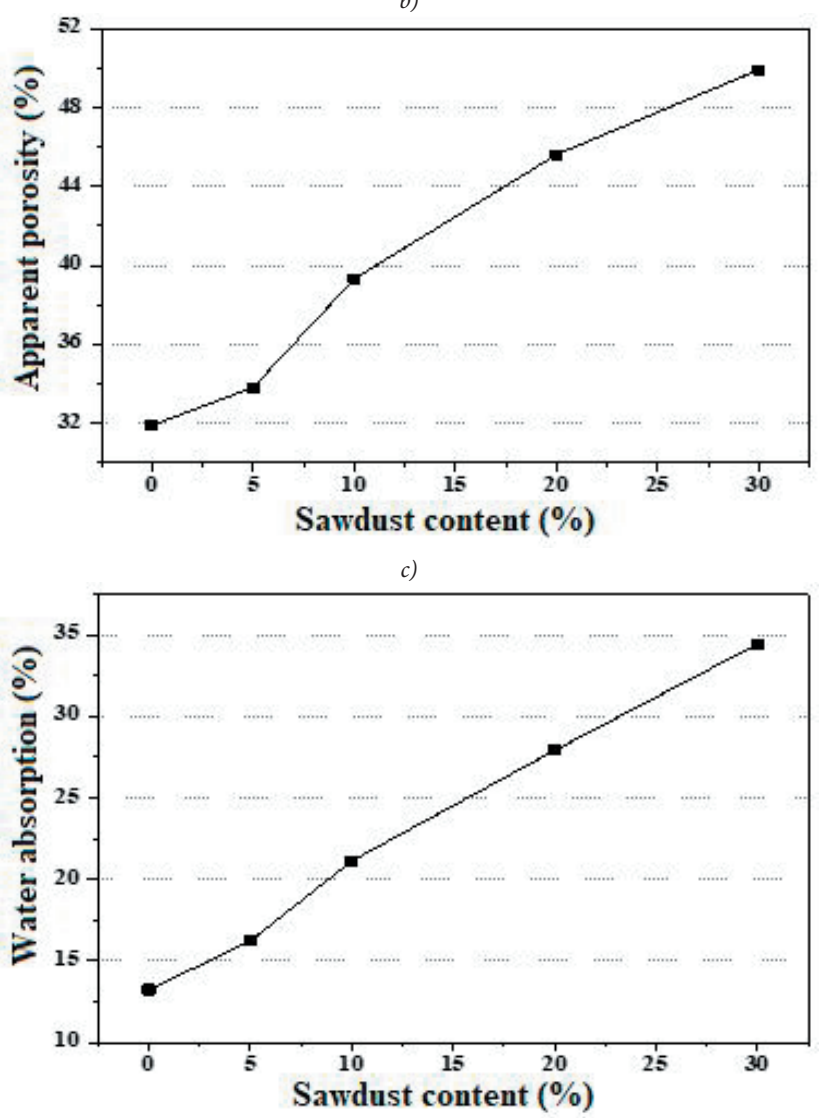

d)

Fig. 11 The correlation between a) weight loss, b) density, c) apparent porosity, and d) water absorption of produced ceramic samples and sawdust content

11. ábra a) a tömegcsökkenés, b) a sürüség, c) a látszólagos porozitás és d) az elöállított kerámiaminták vízfelvétele fürészportartalom függvényében 


\subsection{Technical properties of the produced ceramic samples}

Fig. 11. a shows the weight loss measurements of the different samples. As the sawdust percentage increased in the sample. The weight loss is proportionally increased and reached a maximum value $(23 \%)$ when $30 \%$ of the sawdust is used; the highest value of the weight loss is coming from the decomposition of sawdust in the reduction atmosphere, which leads to carbonization associated gasification process, moreover small amount of weight loss could be assigned to the decomposition of natural zeolite which leads to the evaporation of free water, crystalline water, and $\mathrm{CO}_{2}$.

The density measurement of the prepared samples is illustrated in Fig. 11.b. With increasing the amount of sawdust, the density is noticeably decreased. This could be explained by the carbonization of sawdust which leads to the evaporation of some gases and the formation of less densified samples. This result is in good agreement with the findings obtained from the TG measurement. Moreover, above $1100{ }^{\circ} \mathrm{C}$, decomposition of natural zeolite followed by some physicochemical reaction will take place, which might close the pores and hence increase the density.

The apparent porosity and water absorption are shown in Fig. 11. $c$ and 11. , respectively. The two graphs show quite similar curves since the two properties are connected. Both properties exhibit increase in their value as the amount of sawdust increases. This could be explained by the fact that the carbonization process leads to the evaporation of some gases that produce pores and capillaries inside the samples, therefore increase the porosity and water absorption.

\section{Conclusions}

In-situ carbonization of the sawdust in the composite materials has been successfully carried out in the reduction environment. The sample without sawdust fired into white colour. In contrast, the samples which contain different amount of sawdust fired into black colour indicating the formation of carbon. The XRD analysis confirms the formation of mullite through the reactive sintering process, but it couldn't reveal the occurrence of carbon. This means an XRD amorphous carbon has been formed. The In-situ carbonization, which is associated with gasification, leads to the creation of some pores and capillaries, which affect the technical properties such as porosity, density, and water absorption. This effect can be clearly seen in the SEM images of the produced samples. Thes EDS investigation confirms the formation of carbon. The inclusion of $30 \mathrm{~m} \%$ sawdust in the samples leads to the formation of more than $14 \mathrm{~m} \%$ carbon in the sintered specimens.

\section{Acknowledgments}

The described article was carried out as part of the EFOP3.6.1-16-00011 "Younger and Renewing University -Innovative Knowledge City - institutional development of the University of Miskolc aiming at intelligent specialisation" project implemented in the framework of the Széchenyi 2020 program. The work was performed according to the Government research assignment for ISPMS SB RAS, project FWRW-2021-0005.
References

[1] Shushkov, D. A., Kotova, O. B., Ibrahim, J. F. M., Harja, M., Gömze, L. A., Shchemelinina, T. N., Ignatiev, G. V., (2020) Építőanyag-JSBCM Vol. 72. No. 5. p.156. https://doi.org/10.14382/epitoanyag-jsbcm.2020.26

[2] Huang, H., He, M., Kotova, O. B., Dong, F., Gömze, L. A., Kurovics, E., LV, R., Sun, S., (2020) Építőanyag-JSBCM Vol. 72. No. 4. p.124. https://doi.org/10.14382/epitoanyag-jsbcm.2020.20

[3] Ibrahim, J. F. M., Shushkov, D. A., Kurovics, E., Tihtih, M., Kotova, O. B., Pala, P., Gömze, L. A., (2020) Építőanyag-JSBCM Vol. 72. No. 4. p.130. https://doi.org/10.14382/epitoanyag-jsbcm.2020.21

[4] Kotova, O. B., Shushkov, D. A., Gömze, L. A., Kurovics, E., Ignatiev, G. V., Sitnikov, P. A., Ryabkov, Y. I., Vaseneva, I. N., (2019) Építőanyag-JSBCM Vol. 71. No. 4. p.125. https://doi.org/10.14382/epitoanyag-jsbcm.2019.22

[5] Shchemelinina, T. N., Gömze, L. A., Kotova, O. B., Ibrahim, J. F. M., Shushkov, D. A., Harja, M., Ignatiev, G. V., Anchugova, E. M., (2019) Építőanyag-JSBCM Vol. 71. No. 4. p.131.

https://doi.org/10.14382/epitoanyag-jsbcm.2019.23

[6] Ibrahim, J. F. M., Gömze, L. A., Kotova, O. B., Shchemelinina, T. N., (2019) Építőanyag-JSBCM Vol. 71. No. 4. p.120.

https://doi.org/10.14382/epitoanyag-jsbcm.2019.21

[7] Abdelfattah, M., Kocserha, I., Géber, R., Tihtih, M., Móricz, F. (2020) Evaluating the properties and mineral phases of the expanded clay aggregates with the bentonite additive material, J. Phys. Conf. Ser., vol. 1527, p. 012030, https://doi.org/10.1088/1742-6596/1527/1/012030_

[8] Ibrahim, J. F. M., et al (2020) J. Phys.: Conf. Ser. Vol. 1527. 012029. https://doi.org/10.1088/1742-6596/1527/1/012029

[9] Tihtih. M., et al 2020 J. Phys.: Conf. Ser. Vol. 1527. 012043. https://doi.org/10.1088/1742-6596/1527/1/012043.

[10] Tihtih, M., Ponaryadov, A. V., Ibrahin, J. F. M., Kurovics, E., Kotova, E. L., Gömze, L. A., (2020) Építőanyag-JSBCM Vol. 72. No. 5. p.165. https://doi.org/10.14382/epitoanyag-jsbcm.2020.27

[11] Ibrahim, J. F. M., Mergen, A., Parlak, U., Kurovics, E., Tihtih, M., Gömze, L. A., (2021) Építőanyag-JSBCM Vol. 73. No. 1. p.24. https://doi.org/10.14382/epitoanyag-jsbcm.2021.5

[12] Tihtih, M., Limame, K., Ababou, Y., Sayouri, S., Ibrahim, J. F. M., (2019) Építőanyag-JSBCM Vol. 71. No. 6. p.190. https://doi.org/10.14382/epitoanyag-jsbcm.2019.33

[13] Ponaryadov, A. V., Kotova, O. B., Tihtih, M., Sun, S., (2019) ÉpítőanyagJSBCM Vol. 72. No. 5. p.152. https://doi.org/10.14382/epitoanyag-jsbcm.2020.25

[14] Kurovics, E., Kotova, O. B., Ibrahim, J. F. M., Tihtih, M., Sun, S., Pala, P., Gömze, L. A., (2020) Építőanyag-JSBCM Vol. 72. No. 4. p.144. https://doi.org/10.14382/epitoanyag-jsbcm.2020.24

[15] Gömze L. A., Kurovics, E., (2018) J. Phys.: Conf. Ser. Vol. 1045. 012011. https://doi.org/10.1088/1742-6596/1045/1/012011

[16] Kurovics, E., et al (2020) J. Phys.: Conf. Ser. Vol. 1527. 012034. https://doi.org/10.1088/1742-6596/1527/1/012034

[17] Zeng, K. H., Li, Z. Q., Liang, S. L., Lv, X., Ma, Q. S., (2017) Key Engineering Materials Vol. 727, 461. https://doi.org/10.4028/www.scientific.net/KEM.727.461

[18] Sakka, Yoshio, Donald D. Bidinger, and Ilhan A. Aksay (1995) Journal of the American Ceramic Society Vol. 78 No. 2 p.479. https://doi.org/10.1111/j.1151-2916.1995.tb08827.x

[19] Cui, K., Zhang, Y., Fu, T., Wang, J., Zhang, X., (2020) Coatings, Vol. 10. No. 7. p.672. https://doi.org/10.3390/coatings10070672

[20] Schneider, H., Fischer, R. X., Schreuer, J., (2015) Mullite: crystal structure and related properties, Journal of the American Ceramic Society Vol. 98 No. 10 p.2948. https://doi.org/10.1111/jace.13817

[21] Schneider, H., Eberhard, E., (1990) Journal of the American Ceramic Society Vol. 73. No. 7. p.2073. https://doi.org/10.1111/j.1151-2916.1990.tb05270.x

[22] Serra, M. F., Conconi, M. S., Gauna, M. R., Suárez, G., Aglietti, E. F., Rendtorff, N. M., (2016) Journal of Asian Ceramic Societies Vol. 4. No.1. p.61. https://doi.org/10.1016/j.jascer.2015.11.003

[23] Matveev, V. A., Maiorov, D. V., Kondratenko, T. V., (2020) Glass and Ceramics 1-6. https://doi.org/10.1007/s10717-020-00223-6

[24] Kurovics, E., Kotova, O. B., Gömze, L. A., Shushkov, D. A., Ignatiev, G. V., Sitnikov, P. A., Ryabkov, Y. I., Vaseneva, I. N., Gömze, L. N., (2019) 
Építőanyag-JSBCM Vol. 71. No. 4. p.114. https://doi.org/10.14382/epitoanyag-jsbcm.2019.20

[25] Komarneni, S., Schneider, H., Okada, K., (2005) Mullite Synthesis and Processing, https://doi.org/10.1002/3527607358.ch4

[26] Lewandowski, W. M., Ryms, M., Kosakowski, W., (2020) Processes Vol. 8 No. 5. p.516. https://doi.org/10.3390/pr8050516

[27] Rotich, P. K., (1998) Carbonization and briquetting of sawdust for use in domestic cookers. Diss. University of Nairobi

[28] Srndovic, J. S., (2011) Interactions between wood polymers in wood cell walls and cellulose/hemicellulose biocomposites. Chalmers University of Technology

[29] Yang, J., Ching, Y. C., Chuah, C. H., (2019) Polymers Vol. 11. No. 5. p.751. https://doi.org/10.3390/polym11050751
[30] Bobkova, N. M. (2007) Fizicheskaya Himiya Tugoplavkih Nemetallicheskih i Silicatnyh Materialov, Yvyshej Shaya, Minszk, pp.88-90 [E-book] ISBN 978-985-06-1389-9

Ref.:

Ibrahim, Jamal-Eldin F. M. - Apkarian, Afanasy S. - Tihtih, Mohammed - Kulkov, Sergei N. - Gömze, László A.: In-situ carbonization of natural zeolite-alumina composite materials incorporated sawdust Építőanyag - Journal of Silicate Based and Composite Materials, Vol. 73, No. 4 (2021), 137-144. p. https://doi.org/10.14382/epitoanyag-jsbcm.2021.20

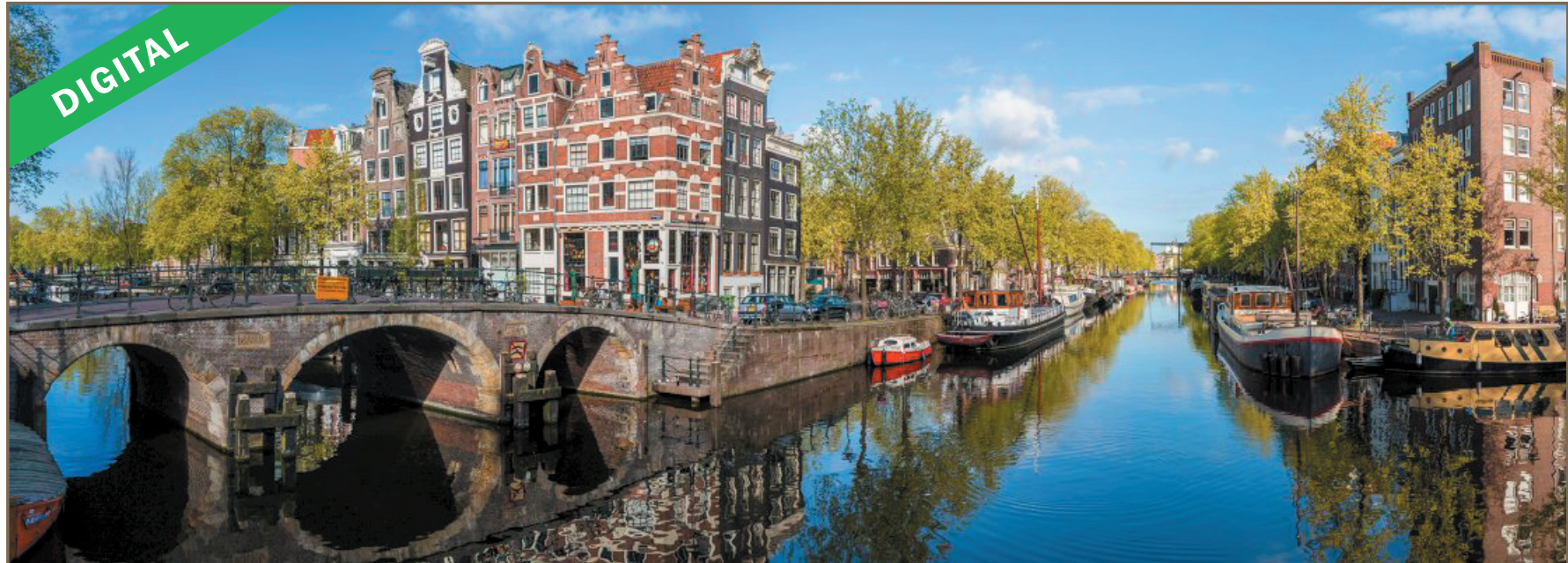

\section{ICCM 2022 \\ XVI. International Conference on Composite Materials August 08-09, 2022 in Amsterdam, Netherlands}

XVI. International Composite Materials is the premier interdisciplinary forum for the presentation of new advances and research results in the fields of Materials and Metallurgical Engineering.

Today more than ever before it is extremely important to stay abreast of the changing landscapes of the Materials and Metallurgical Engineering world. The multidisciplinary focus of this event aims to bring together presenters and attendees from different fields with expertise in various areas of Materials and Metallurgical Engineering, providing an excellent opportunity to participate in the international exchange of ideas, current strategies, concepts and best practices, collaborations, and cooperation, offering a broader perspective and more enriching experience.

The program includes time allocated for networking, peer-to-peer discussions, and exploring the host city.

We invite the participation of leading academic scientists, researchers and scholars in the domain of interest from around the world to submit original research contributions relating to all aspects of:

- Additive manufacturing

- Applications

- Bio-based composites

- Biomimetic composites

- Ceramic matrix composites

- Concrete and cementitious composites

- Damage and fracture

- Durability and ageing

- Experimental techniques

- Fibers and matrices

- FRP reinforced concrete

- Health monitoring

- Hybrid composites
- Infrastructure

- Interfaces and interphases

- Interlaminar reinforcements

- Joint and bearing behaviour

- Life cycle analysis and sustainability

- Low cost technologies

- Mechanical and physical properties

- Metal matrix composites

- Multifunctional composites

- Multiscale modelling

- Nanocomposites

- Nanotechnologies

- NDE technologies
- Polymer matrix composites

- Probabilistic approaches and design

- Processing and manufacturing technologies

- Recycling

- Repair technologies

- Sandwich technologies

- Standardisation

- Structural design

- Testing and characterization

- Textile composites 